\title{
K UDRŽITELNOSTI LOKÁLNÍCH RECENZOVANÝCH NEIMPAKTOVANÝCH ČASOPISŮ S DŮRAZEM NA PROFESIONALIZACI A VĚDECKOU KOMUNIKACI
}

\section{Vážené čtenářky a čtenáři,}

vítáme vás u podzimního čísla časopisu ProInflow. Toto číslo je kratší, než jste zvyklí z čísel předchozích. S ubývajícím př́livem nových článků, které navíc musejí přestát test kvality v podobě recenzního řízení, je stále obtížnější udržet alespoň minimální počet článků, které by vydaly na plnohodnotné číslo časopisu. Příčin je celá řada, některé z nich nastíníme po uvedení čtenáře do obsahu tohoto čísla. Přesun časopisu do nového systému se zatím stále neuskutečnil, jeho využití je totiž podmíněno dohodou mezi různými odděleními univerzity, pod jejíž záštitou je časopis publikován. Přesun do nového je tak více otázkou politického vyjednávání a shody, která je mimo působení členů redakce. Na svůj nový kabát tak ProInflow stále čeká.

V následujícím čísle čtenář najde tři původní recenzované statě. V první výzkumné studii nás Adéla Jarolímková a Barbora Drobíková seznamují s proměnami služeb knihoven během prvních dvou vln covidové pandemie. Druhá výzkumná studie kolektivu autorů vedeného Jiřím Kratochvílem se věnuje citačním praktikám v biomedicínských časopisech a jejich odklonu od názorů editorů časopisů. Posledním zveřejněným článkem je koncepční studie vizualizace dat jako nástroje k překonávání bariér u lidí znevýhodněných v oblasti vizuálního vnímání od Tomáše Marka.

Kde hledat příčiny problémů s udržitelností vydávání profesních recenzovaných časopisů vycházejících $\mathrm{v}$ českém jazyce? Mezi přičiny patří nedostatečná motivace výzkumníků publikovat právě v česky psaných a neimpaktovaných časopisech, dále nedostatečná sebedůvěra odborníků z praxe a rozpory ohledně oborové profesionalizace. V České republice je málo odborníků věnujících se výzkumu v oboru, ale široká nabídka oborových přístupů, specializací a témat. Je velmi pravděpodobné, že publikováním výsledků výzkumů v češtině mine výzkumník svoji referenční skupinu. Pokud však budou výzkumníci publikovat v anglickém či jiném zahraničním jazyce, bude odborná terminologie v národním jazyce zastarávat a nebude obohacovaná o nové termíny, čímž ztratí schopnost reflektovat aktuální poznání.

Výzkumníci jsou také motivováni k publikování výsledků výzkumu v časopisech indexovaných ve vybrané množině časopisů, potažmo databází, které jim zajistí dostatečné množství bodu v Registru informací o výsledcích dle MŠMT. Přijetí tuzemského časopisu do indexované databáze vyžaduje, aby časopis měl stabilní množství článků a současně aby recenzní řízení vykazovalo kvalitu, a tedy 
docházelo $\mathrm{k}$ filtrování obsahu a část $\mathrm{z}$ předložených článků nebyla $\mathrm{k}$ publikování přijata. $\mathrm{V}$ této konstelaci připomíná tuzemský recenzovaný časopis psa, který se honí za vlastním ocasem. Bolestivá je také spolupráce s recenzenty, zvláště těch z oborů informační věda a knihovnictví. Standardním problémem je vytíženost odborníků, kvůli které nemají čas na recenzní činnost. Oborovou zvláštností jsou však četná odmítnutí ze strany odborníků působících v praxi, obzvláště těch pracujících v knihovnách. Z jejich strany často narážíme na odmítnutí kvůli pocitu nedostatečné odbornosti, pochybách o vlastních schopnostech zhodnotit či sepsat posudek na odborný text. Tento stav otevírá řadu znepokojivých otázek, které by samy o sobě zasloužily systematické prozkoumání: Znamená to, že v naší zemi dělají odbornou práci neodborníci? Nebo to značí nízkou sebedůvěru ve vlastní schopnosti a znalosti? Je sebepodceňování doménově podmíněné, tj. je charakterovým rysem profesionálů v oboru?

Poslední z obecných přičin obtíží recenzovaných časopisů v oboru jsou posuny důrazů v oborové profesionalizaci. Profesionalizace je transformací pracovních činností vykonávaných v rámci zaměstnání do profese, která má ve struktuře společnosti vyšší umístění, a tudíž vyšší prestiž (Suda, 2018; Despotović, 2012). Profesionalizací označujeme společný proces vývoje „pracovních skupin, které kontrolují získávání a uplatňování různých druhů znalostî“ (Abbot, 1988, s. 1). Ustavení statusu profese obvykle provází několik charakteristických rysů či organizačních vzorů: ustavení jedné či více profesních organizací prosazující normy chování, institucionalizací tohoto chování např. pomocí etických kodexů, ale také pomocí specializovaného vzdělávání na odborných či vysokých školách nebo pomocí certifikovaných zkoušek. Každá profese je navíc v neustálém boji o ustavení a udržení hranic svojí jurisdikce, v níž hraje zásadní roli teoreticko-abstraktní zázemí oboru a jeho přesvědčivost pro zákonodárné orgány (Abbot, 1988). Informační vědy a knihovnictví jsou vystaveny bojům s jinými profesemi na řadě míst. Např. v oblasti digitálního a informačního vzdělávání je to spor s pedagogickou profesí o otázky spojené s expertízou v didaktice, v oblasti digitálních knihoven či získávání informací jde o spor o jurisdikci s počítačovými vědci, jejichž expertíza substituuje expertízu knihovníků a informačních vědců. Pozvednout prestiž profese se snažil prof. Cejpek (2004) návrhem profesní uzávěrky - ustavením demarkační linie mezi laiky a knihovníky na základě bakalářského titulu v oboru. Mezi významnými personami oboru však lze zaznamenat i opačné pohledy, které tvrdí, že pro vykonávání knihovnického povolání není třeba vysokoškolského vzdělání, které se pro efektivní výkon zaměstnání nehodí. V situaci zpř́ísňujících se nároků na univerzitní vzdělání je důsledkem chybějící profesní uzávěrky nedůvěra k roli a významu teoretického významu a abstraktního promýšlení oborových otázek, což může paradoxně prospívat konkurenčním profesím a významně ohrožovat nejen profesi, ale i samotné zaměstnání, které by mohlo sklouznout k roli pouhého skladníka fyzických knih. Profesní rozpolcenost také dopadá na ochotu vystavovat se odmítnutí výsledků vlastní práce v recenzním řízení. Situace patrně souvisí také s již zmíněnou nižší sebedůvěrou profesních odborníků. 


\section{Literatura:}

Abbot, A. The System of Profession. Chicago: The University of Chicago Press, 1988.

Cejpek, J. Prestiž knihovnického povolání. Čtenář: měsičník pro knihovny. 2004, roč. 56(12), s. 382384.

Despotović, M. Vzdělávání dospělých mezi profesionalizací a profesionalismem. Studia paedagogica. 2012, 17(1), 75-90. DOI 10.5817/SP2012-1-5.

Suda, Z. Profesionalizace [online]. In Nešpor Z. R. a O. Vodáková. Sociologická encyklopedie. 2018. [cit. 2021-10-28]. Dostupné z: https://encyklopedie.soc.cas.cz/w/Profesionalizace. 